\title{
Research on Innovative Entrepreneurship Practice Education of Female College Student
}

\author{
Nan Niu \\ Teaching Services Office, Shandong Women’s University, Jinan, Shandong, 250300
}

Keywords: female college student; innovative entrepreneurship; practice education

\begin{abstract}
Female entrepreneurship is a sign of social civilization progress. As a representative of intellectual women, female college students not only have some characteristics of the ability and quality of traditional female entrepreneurs, but also have different characteristics created under the conditions of the new era. In response to Premier Li Keqiang's concept of "mass entrepreneurship and innovation", under the current severe employment situation, encouraging female college students to start a business has become a way out and countermeasures to alleviate the employment pressure of female college students and solve employment problems. Through entrepreneurship education, colleges and universities can guide female college students to improve their entrepreneurial awareness and ability, and join the ranks of entrepreneurship, not only contribute to society, but also highlight women's self-worth, which is the embodiment of modern women's independence.
\end{abstract}

\section{Introduction}

In today's "mass entrepreneurship, innovation", the innovation and entrepreneurial boom swept the country. The enthusiasm of women entrepreneurship in the country is rising, and the promotion of their own innovation consciousness and entrepreneurial ability has become an urgent need of college girls. However, the current innovation and entrepreneurship education of colleges and universities can not meet the needs of girls to enhance their ability to innovate and start their own businesses. Promoting the reform of innovation and entrepreneurship education in colleges and universities, paying attention to girls' innovation and entrepreneurship education, and enhancing girls' ability of innovation and entrepreneurship are the needs of girls' own development under the dual-creation environment, the needs of society, the need of college education, and the importance of promoting the research of college girls' innovation and entrepreneurship education. And necessity.

\section{The Status Quo of College Students' Innovative Entrepreneurship Education}

In recent years, colleges and universities have made substantial progress in innovation and entrepreneurship education. From the initial utilitarian and formal education to the goal of cultivating innovative and entrepreneurial talents, the real innovation and entrepreneurship education; from the initial entrepreneurship education to the education of "innovation + entrepreneurship"; from the emphasis on theory to the combination of theory and practice. Innovative entrepreneurship education; from elite education to popular innovation and entrepreneurship education; from isolated education to innovative and entrepreneurial education integrated into professional education. Driven by the reform of innovation and entrepreneurship education in colleges and universities, more and more students are involved in the study and practice of innovation and entrepreneurship education, and the wave of social entrepreneurship has swept the campus. At the same time as the innovation and entrepreneurship education in colleges and universities is in full swing, compared with boys, girls pay more attention to innovation and entrepreneurship education in colleges and universities, participation in innovation and entrepreneurship practice, and enthusiasm for innovation and entrepreneurship are far lower than boys. The research team published a questionnaire on the status quo of girls' innovation and 
entrepreneurship education in Shandong universities through questionnaires. Up to now, 101 female students have participated in the survey. According to the statistics of the questionnaires, girls participating in the survey generally believe that their universities attach importance to innovation and entrepreneurship education, but they also generally believe that Colleges and universities do not pay enough attention to girls' innovation and entrepreneurship education, and there are few innovations and entrepreneurship education for female college students. Innovative and entrepreneurial education in colleges and universities still emphasizes theory and practice, and girls lack opportunities to participate in innovation and entrepreneurship practice. The survey data also shows that female college students' interest and attention to innovation and entrepreneurship education is gradually increasing. More and more girls are paying attention to the cultivation of their own innovative and entrepreneurial abilities, eager for the training of innovative entrepreneurial knowledge and skills training, and they are eager to pay attention to colleges and universities. Innovative entrepreneurship education for girls, providing courses for girls' innovation and entrepreneurship education, and supporting girls' innovation and entrepreneurship practices. The urgent need for girls to innovate and innovate in colleges and universities reflects the lack of colleges and universities in promoting girls' innovation and entrepreneurship education from another angle.

Innovative entrepreneurship education in colleges and universities ignores gender differences and neglects the demand for girls in innovation and entrepreneurship education courses. Through research and review of information, up to now, in addition to some colleges and universities such as Shandong Women's College and other special courses for girls and related support, there are few innovative and entrepreneurial education for colleges and universities. Innovative entrepreneurship education is still different. The mainstream of innovation and entrepreneurship education in colleges and universities. In the innovation and entrepreneurship education of colleges and universities, women should be paid attention to and support.

\section{Characteristics and Shortcomings of Current Female College Students' Entrepreneurship}

At present, the characteristics and advantages of female college students' entrepreneurship are mainly as follows: First, the characteristics and advantages of their own physiological conditions. The advantages of women's entrepreneurship are as follows: female college students have meticulous patience and thoughtfulness; communication skills, coordination, and management skills; and the advantages and qualities of affinity, positive and steady, and serious practicality. These are the qualities necessary for entrepreneurship. Second, professionalism and ability to provide modern technology and intellectual services with the times. Today, female college students are generally more solid in learning professional knowledge than boys. Therefore, in the process of entrepreneurship, their comparative advantage is to have a solid professional and technical knowledge, they can combine their own professionalism in the field of modern technology and intellectual services, and combine the knowledge and practice. Third, it is more suitable for the secondary and tertiary industries where physical strength is not obvious. Women are physically weaker than men, so it is rare for women to start a business in the primary industry with large physical expenditures. At present, women's entrepreneurship is mainly concentrated in the secondary and tertiary industries in the industry. Studies have shown that in the service industry, education, business, information consulting and other industries, female college students are more advantageous than boys.

However, due to the influence of traditional concepts and women's own characteristics, there are still some disadvantages and shortcomings in the process of entrepreneurship: First, there are certain deficiencies in entrepreneurial awareness and concepts. Although today's society advocates equality between men and women, the traditional ideas of thousands of years can not be changed overnight. People always think that "male outsiders" and "female owners", after graduating from female college students, find a stable job to achieve economic independence. Just fine. Influenced by traditional concepts, female college students generally have weak entrepreneurial motivation and weak entrepreneurial awareness. The enthusiasm of entrepreneurship is not high, which seriously 
affects the development of women's potential and utility. Second, the quality and ability of entrepreneurship needs to be improved. Due to the influence of women's own characteristics, female college students have serious problems of dependence, poor ability to withstand risks, and lack of strategic vision. A considerable number of female university students have a strong sense of stability, an open mind is not broad enough, they cannot grasp the opportunity, accurately grasp the opportunities for entrepreneurship, and cannot formulate long-term strategic development plans. These have become potential factors hindering their further development in the entrepreneurial process.

\section{Countermeasures to Promote Female College Students' Entrepreneurship Education}

In view of the current characteristics of female college students' entrepreneurship and the shortcomings of entrepreneurship education, we should start from the previous aspects: First, establish a correct entrepreneurial concept and stimulate female entrepreneurs' entrepreneurial awareness. In order to establish a correct concept of entrepreneurship for female college students and to stimulate the entrepreneurial awareness of female college students, the entrepreneurial guidance department of colleges and universities not only provides guidance on gender roles for female college students, but also raises the awareness of female college students about entrepreneurship and helps them understand and understand the importance of entrepreneurial quality. In addition to correct self-employment concept, female college students must also regulate students' ideology and behavioral awareness, strengthen female college students' personality cultivation, cultivate their firm and optimistic psychological quality, help female college students to form good entrepreneurial quality, and promote female college students to carry out entrepreneurial activities. Improve the success rate of female college students.

Pay attention to the cultivation of female college students' entrepreneurial quality and ability. The quality and ability of entrepreneurship is a key factor in the success of entrepreneurship. Therefore, it is necessary to pay attention to the cultivation of female college students' entrepreneurial quality and ability, and focus on cultivating female college students' innovative creativity, independent autonomy, courage and pioneering ability and professional technical ability. Combine the current background of big data and Internet conditions to exercise innovative ability in learning life. Accumulate your expertise and use your expertise to start a business.

Establish a special curriculum system suitable for female college students to start their own businesses. Colleges and universities offer special courses on female entrepreneurs' entrepreneurship education. First of all, colleges and universities should set up elective courses suitable for female gender characteristics in the teaching plan to guide female college students to correctly understand the advantages and disadvantages of entrepreneurship. The implementation of female college students' entrepreneurship education in colleges and universities should take into account the characteristics of female college students. At the same time as the teaching theory courses on entrepreneurship foundations such as entrepreneurial finance, entrepreneurship planning, enterprise management, marketing, and human resource management, it is necessary to add female characteristics courses in combination with female gender characteristics. Such as "female studies", "women's sociology", "family social science" and other elective courses. At the same time, the psychological education health curriculum should be incorporated into the university entrepreneurship education system, and courses such as "Female Psychology" and "Female College Students' Psychological Quality Cultivation" should be established, and psychological counseling activities should be carried out in a targeted manner to impart psychological knowledge and psychological counseling. To help female college students solve psychological confusion and behavioral obstacles in the process of entrepreneurship education, to stimulate the confidence and perseverance of female college students to start a business, and to guide them to correctly treat life and difficulties.

Strengthen the construction of the faculty of entrepreneurship education. Encourage university teachers to "go out" to participate in entrepreneurship training, conduct academic exchanges, and go to the enterprises and industries to further enhance the entrepreneurial guidance ability of teachers. 
The school can also hire some successful female entrepreneurs, outstanding alumni and female experts to "walk in" as a part-time tutor to start a business seminar, share entrepreneurial experiences and experiences with female college students, and let female college students understand the latest entrepreneurial developments. To guide and pilot.

Carry out a variety of teaching practices in entrepreneurship education. Entrepreneurship education should not stay on the level of "paper talk", and it is necessary to carry out a variety of teaching practices in entrepreneurship education, such as through school-enterprise cooperation, establish a school-enterprise joint venture practice base, through field teaching, from excellent business management. Learning experience and skills, guiding female college students to actively participate in entrepreneurial practice, laying the foundation for future entrepreneurship. Another example is the launching of a business plan competition, which is also an effective way for college students to simulate entrepreneurship. Through the business plan competition, students can use their own entrepreneurial knowledge in the actual operation, familiar with the entrepreneurial process, get simulated entrepreneurial experience, exercise team spirit, organizational management ability and communication skills, the rights content and power exercise mode and China Corporate law and corporate law practices are not compatible. A large number of workers' congresses in the real society need to reshape the position and authority of the workers' congress, and China has not yet had a unified law that adapts to the development of the workers' congress. A large number of workers' congresses emerging in economic life should form a "forced" of the workers' congress legislation. Moreover, the improvement of the Staff Representative Conference system will certainly promote the establishment of the Workers' Congress in China to usher in a new peak.

\section{Conclusion}

In view of the grim situation in the current market, higher vocational colleges must pay attention to innovative education with the core of improving the employment ability of apparel majors. From the three aspects of schools, teachers and students, we will continue to improve the employability of clothing students. With the theme of promoting quality education as the core, improving the quality of personnel training, and aiming at cultivating innovative talents, we will promote the close integration of higher education with science and technology, economy and society, and accelerate the cultivation of innovative and entrepreneurial talents with innovative spirit and courage to participate in practice.

\section{References}

[1] Yang Xiaohui. Research on Entrepreneurship Education and Innovative Talents Cultivation in Colleges and Universities in China [J]. China Higher Education Research, 2015(2): 39-44.

[2] Qian Xiufang, Zhao Xiaorong. Study on the Problems and Countermeasures of College Students' Entrepreneurship Education [J].Time Education, 2017(11):26.

[3] Chen Ling. Opportunities and Challenges: Research on Self-employment of Female University Graduates in Colleges and Universities [D]. Zhengzhou: Zhengzhou University, 2010.

[4] Ma Yongbin, Bai Wei. Research and Exploration on the Practice Mode of University Innovation and Entrepreneurship Education [J]. Teaching Research of Tsinghua University, 2015(6): 99-103.

[5] Xu Yuanyuan, Yang Landing. Analysis of Female College Students' Entrepreneurship Education [J]. Education, Space and Time, 2010(03): 28. 